\title{
Applied Systems Theory and Financial Systems. An empirical research of a model with moderate variable added on the "CSR - CFP" linear relationship.
}

\author{
Qi Tai Song Shen ${ }^{1 *}$, Xiao Fei Wang ${ }^{2}$, Jian $\mathrm{Yu}^{2}$ \\ ${ }^{1}$ Research Center of Digital Transformation and Social Responsibility Management \\ Zhejiang University City College \\ Hangzhou, 310015 \\ China \\ ${ }^{2}$ School of Management, Hangzhou Dianzi University \\ Hangzhou,310018 \\ China
}

Received: December 22, 2020. Revised: July 12, 2021. Accepted: July 25, 2021. Published: July 28, 2021.

\begin{abstract}
In Systems Theory the financial Systems Engineering plays an important role. Whether the social responsibility of state-owned enterprises can also have a significant impact on economic performance is an important problem worthy of further exploration. Based on the stakeholder theory, this study using high-quality management theory and upper echelons theory along with the second-hand data from different sources, empirically analyzes the relationship between "corporate social responsibility (CSR) and corporate financial performance (CFP)" of 285 Chinese state-owned listed companies. This study simultaneously introduces the level of executives' shareholding ratio (ESR) to explore the contingent effect of this relationship. This research finds that, unlike some previous results, the CSR of state-owned listed companies significantly positively affects the CFP of the subsequent years'; More importantly, the level of executives' shareholding ratio will amplify the above relationship and play the role as the positive moderate effect. From the perspective of corporate governance, this study promotes the research on the influence mechanism of Chinese state-owned enterprises' social responsibility performance, reveals the important contextual factors which positively stimulate the relationship between "CSR-CFP", and has important enlightenment and practical significance for the development of strategic social responsibility theory and the optimization of the corporate governance of the state-owned listed companies.
\end{abstract}

Keywords-Systems Theory, Financial Systems, Applied Systems Theory, Systems and Control, Corporate social responsibility, moderate model, state-owned listed companies, executives' shareholding ratio.

\section{INTRODUCTION}

JN Modern Systems Theory the mathematical modelling and $\mathbf{I}_{\text {simulation plays an important role. Applied Systems Theory }}$ and Financial Systems have received considerable attention among the researchers and practitioners recently. In the past 40 years of reform and opening-up, China has achieved great economic achievements, but also highlighted social responsibility problems such as "employment discrimination, environmental pollution, poor quality, lack of credibility, tax evasion, and bribery". In this regard, the academic community has made many efforts to prove that "the company can make money by doing good", to persuading the supporters of "shareholders' interests first" and refuting the view that companies should not use redundant resources for socially responsible actions [1]-[5]. But the conclusions of the relevant research are seriously inconsistent [6].

The existing research evidence has primarily been gathered in developed countries. If we consider the special nature of China's market economy and institutional system, however, it is unclear whether CSR influences competitive advantage. By comparing the research on the relationship between corporate social responsibility (CSR) and financial performance, we found that the selected samples are more generalized, lack of specific research on specific industries and ownership enterprises, and empirical analysis using second-hand data is even rarer. Therefore, it is of value to further test secondary data pertaining to this relationship in China. In the Chinese political and economic context, state-owned enterprises have strong 
economic control and social influence, and scholars have increasingly begun to focus on social responsibility problems at Chinese state-owned companies. However, most related studies only present theoretical models or analytical frameworks [7]. Sufficient quantitative evidence is lacking, and where there is such evidence, conclusions are inconsistent [8]. For instance, Yang and Deng believe that the relationship between CSR and corporate financial performance (CFP) is not obvious [9]. Wang and Wang suggest that a linkage between CSR and CFP such that they mutually promote one another [10]. Zhu et al. propose varying forms of influence on CFP according to different CSR dimensions [11].

Through literature review, we noted that, Aguilera et al. [12] propose placing the emphasis on moderating effects in the relationship between CSR and CFP, by considering, for example, "what type of organization or condition may generate effective actions of responsibility". Johnson and Greening, Peng and Yang focus more directly on corporate governance and other situational factors [13], [14]. After this, other researches have explored the moderating effects of corporate governance factors on CSR-CFP relationship such as ownership concentration, gender diversity of the board of directors, board members and board independence. However, from the author's perspective, except for a small number of studies (e.g., Li and Zhang [8]), the quantitative research on the CSR-CFP relationship is inadequate.

Based on the stakeholder theory, quality management thinking and the upper echelons theory and following the perspective of strategic social responsibility, this research will take the empirical research by using 285 state-owned listed enterprises from 2011 to 2013 as samples. In addition, using social responsibility assessment data of third parties with strong credibility and the financial indicators of listed companies, theoretical discussion is offered and empirical analysis conducted. Through this approach, this study seeks to reveal the influence and internal mechanism of the social responsibility of state-owned companies in China on financial performance and to analyze the effect of corporate governance factors (e.g., the shareholding ratio of executives) on the CSR-CFP relationship. Based on that, this research is to reveal the mechanism black box and theoretical boundary of this causal relationship chain. We are going to explore the mechanism that promotes the integration of social responsibility into strategy by the senior executives' team, and to provide empirical evidence and enrich the literature on strategic social responsibility research, and to provide new ideas and decision-making basis for the reform and development of China's state-owned enterprises.

The remainder of this paper is organized as follows. First, a literature review is provided and the testable hypotheses are developed in Section II . Next, Section III introduces samples and data, variables, and models for the empirical analysis. Then, Section IV presents and analyzes the empirical results. Finally, concluding remarks and recommendations are presented in Section $V$.

\section{Literature ReVIEW AND Hypothesis}

\section{A. Potential Mechanism of the Influence of State-owned Enterprise CSR on CFP}

As noted in the introduction, although many scholars believe that CSR directly influences CFP [15], research conclusions regarding the relationship between CSR and CFP are complex. Certain neoclassical economists believe that social responsibility increases direct costs [16]. We know that the stakeholder theory, which has been widely accepted among academics, is an important basis for examining the CSR-CFP relationship. In addition, we believe that by examining state-owned listed companies one can further integrate quality management ideas based on stakeholder analysis [17], [18]. Only change-oriented analysis can overcome static thinking and reveal the substantial impact of the fulfillment of social responsibility by state-owned listed companies on CFP. This theory states that the key to corporate efficiency enhancement and strategic realization is quality management, whose essence is efficiency improvement based on efficiency goals. On the one hand, quality management helps enterprises better identify and interpret internal and external stimuli, enhance their resource integration and coordination capabilities and increase innovation awareness and profitability. On the other hand, it helps companies detect and prevent risks, reduce unnecessary resource consumption and improve the relationship between the enterprise and key stakeholders [17], [18].

Based on this view, this study argues that when state-owned enterprises correctly understand and integrate CSR, they strengthen their "efficiency awareness, customer awareness, sense of innovation, and meticulous management awareness" and find important opportunities to reduce resource loss, which facilitates deep reforms, structure optimization and the transformation of development methods. This statement is particularly applicable to large state-owned enterprises, in which because of their scale characteristics, the embedding of social responsibility exerts the scale effects and the scope effects that substantially enhance the trust and satisfaction of stakeholders and improve financial performance. For example, the improvement of CSR can enhance employee loyalty and government trust [12], [19], increase the satisfaction of consumers and the public, weaken potential assessment pressure of environmental governance assessment, and enhance the confidence of the capital market. Whether it is a reduction in operating costs or an increase in operating income, it will greatly increase the economic efficiency and market value of the enterprise [20]. Notably, given that state-owned enterprises are generally good at implementing "top-down" strategies, the scale and scope effects of quality management improvement can also be expected in the short term. Thus, we propose the following hypotheses.

H1a: CSR positively influences CFP based on the accounting indicators of state-owned listed companies.

H1b: CSR positively influences CFP based on the capital market indicators of state-owned listed companies. 


\section{B. Impact of executives' shareholding ratio on the CSR-CFP Relationship}

A research topic that originated in debates on traditional corporate theories [16], CSR has always long been a focus of scholars in corporate governance [12], [13]. For example, Li and Zhang examine the relationship between equity dispersion in state-owned and private enterprises and CSR [8], and Kabir and Thai analyze the effect of controlling rights [21], board size and independence on CSR performance. However, in addition to analyzing ownership structure [14], one can investigate state-owned listed companies on the basis of upper echelons theory and in connection with information asymmetry, executive decision motivation and other principal-agent problems [22]. As noted in the theory and demonstrated in empirical studies, under limited rationality, managers influence the company's strategic type and intention based on their own preferences and value orientation, which in turn affects corporate performance. For example, Petrenko et al. reveal that CEO narcissism is positively related to CSR, which affects the relationship between the past and current charity images [22]. Therefore, based on upper echelons theory, we can expect that when the management team has better incentives (e.g., in terms of the shareholding level of executives), its management rationality and decision-making responsibility will be strengthened, and the principal-agent problems will be weakened. The management team will utilize the advantage of relatively sufficient information to rationally consider the company's resources and capabilities while carefully analyzing different strategic models of social responsibility, the varied business relevance of social responsibility and differing responsibility participation methods [23]. Thus, we propose the following hypotheses.

H2a: The shareholding ratio of executives positively affects the relationship between the CSR of state-owned listed companies and CFP based on accounting indicators.

H2b: The shareholding ratio of executives positively affects the relationship between the CSR of state-owned listed companies and CFP based on capital market indicators.

\section{METHODOLOGY}

\section{A. Sample and Data Sources}

This study selected 300 companies from the CSR ranking list of state-owned listed companies published in Southern Weekend in 2011-2013 as its sample. To avoid differences in the social responsibility system regulation and financial measurement methods of different exchanges and to ensure the comparability of the CSR and CFP information of listed companies, we exclude listed state-owned enterprises overseas (such as Hong Kong, China) and listed enterprises with incomplete information. A total of 285 state-owned companies listed on the Shanghai and Shenzhen stock markets were included in the final sample. The corresponding CFP information for the sample enterprises is adopted from the GuoTaiAn CSMAR database and the Tonghuashun Financial database. The corporate governance indicator data are drawn from the GuoTaiAn CSMAR database. The authors matched the code and indicator year of each listed company.

\section{B. Model Construction and Variable Definition}

This study focuses on analyzing the CSR of year $t$ and the impact of the shareholding ratio of executives and other related variables on CFP in year $t+1$. In this way, we reduce the reverse causality problem and exclude endogenous problems to an extent. According to the research hypotheses, this paper constructs multivariate regression models (Model 1 and Model 2):

$$
\begin{aligned}
& \text { ROE }_{t+1}=\gamma_{0}+\gamma_{1} \text { CSR }_{t}+\gamma_{2} \text { ESR }_{t}+\gamma_{3} \text { CSR }_{t} * \text { ESR }_{t} \\
& +\gamma_{4} \text { Size }_{t}+\gamma_{5} \text { Stru }_{t}+\gamma_{6} \text { Risk }_{t}+\gamma_{7} \text { Yeardum }+\varepsilon_{1} \\
& \text { TQ }_{t+1}=\eta_{0}+\eta_{1} \text { CSR }_{t}+\eta_{2} \text { ESR }_{t}+\eta_{3} \text { CSR }_{t} * \text { ESR }_{t} \\
& +\eta_{4} \text { Size }_{t}+\eta_{5} \text { Stru }_{t}+\eta_{6} \text { Risk }_{t}+\eta_{7} \text { Yeardum }+\varepsilon_{2}
\end{aligned}
$$

The variable measurement conditions involved in the study are reported as follows.

1) Dependent variable. In the literature, CFP is mainly measured in three modes: accounting performance indicators, market performance indicators, and perceived comprehensive performance. This study follows previous scholars, in measuring financial performance by jointly using the accounting-based performance indicator (ROE) and a market-based performance indicator (Tobin's Q) [20], [24]. ROE primarily measures the utilization of corporate internal resources whereas Tobin's Q focuses on the forward-looking view of investors with respect to a company's market value relative to its book value. Specifically, ROE is measured by the ratio of net profit to shareholders' equity. Tobin's Q is originally measured by the ratio of the company's market value to the replacement of assets.

2) Independent variable. CSR measurement has long been a research focus and perennial source of difficulties. In the literature, CSR measurement primarily includes content analysis, questionnaire surveys and third-party indicator substitution. This study follows the research trend of increasingly using CSR assessment results released by professional organizations or social media [25]. The CSR ranking data published by Southern Weekend were selected for this research based on a comprehensive consideration of the objectivity, professionalism, and availability of the data.

3) Moderating variable. We select the shareholding ratio of executives (ESR) as the moderating variable to extensively analyze the relationship between the CSR and CFP of state-owned listed companies. According to the GuoTaiAn CSMAR database and definitions in the literature, "the executive team" refers to the senior management staff disclosed in the annual report of the listed company (including senior executives who are concurrently directors). Other. The shareholding ratio of the senior management team refers to the proportion of the company's 
shares held by all senior executives to the company's total shares. This study selects the shareholding ratio of the senior management team as the moderating variable, related information is also from the GuoTaiAn CSMAR database.

4) Control Variable. Based on previous studies, we introduce four control variables: enterprise size, shareholding structure, enterprise risk, and data year [15], [17], [18], [26]. In the research model, Size, Stru, Risk, and Yeardum are used to represent the control variables. The relevant information regarding each variable is from the GuoTaiAn CSMAR and Tonghuashun databases. Specifically, the size of an enterprise is measured by the total number of employees. The shareholding structure is measured by the ratio of listed shares to total equity. The enterprise risk is measured by asset-liability ratio (the ratio of total liabilities to total assets). The data year control variables in this study use dummy variables, with "1" for 2011 and "0" for 2012.

\section{Data Analysis AND Discussion}

\section{A. Descriptive Statistics and Correlation Analysis}

Table I provides a descriptive statistical and correlation analysis of the main research variables. As shown in the table, the overall level of social responsibility of Chinese state-owned enterprises remains in the developmental phase and has much room for growth. State-owned enterprise social responsibility is significantly positively correlated with return on net assets and company size and negatively correlated with the proportion of tradable shares, which supports the theoretical hypotheses to a certain extent.

\section{B. Regression Results and Discussion of the Basic Model}

This study uses hierarchical regression to test the research Table I. Means, standard deviations, and correlations. models based on SPSS23. Table II shows the basic model. Only control variables and independent variables are input into both Model 1 and Model 2. It can be seen from Table II that the $\mathrm{F}$ values in Model 1 and Model 2 are significant at the $0.1 \%$ and $1 \%$ levels, respectively. These outcomes indicate that the models have a good fit. The D.W. values are approximately 2 , which indicates there is no autocorrelation between the residuals. The variance inflation factor (VIF) values are all below, indicating no significant multicollinearity between the respective independent variables. In Model 1, we find that after controlling for enterprise size, the capital structure of the enterprise and the structure of the share capital, the CSR of year t still significantly positively affects the company ROE of the year $\mathrm{t}+1(\beta=0.302 ; \mathrm{p}<0.01)$. Therefore, Hypothesis $1 \mathrm{a}$ is supported. In Model 2, CSR in year $t$ also significantly positively affects Tobin's $\mathrm{Q}$ at year $\mathrm{t}+1(\beta=0.242 ; \mathrm{p}<0.05)$. Therefore, Hypothesis $1 \mathrm{~b}$ is also supported.

The author noted that the conclusion supported by Hypothesis 1a echoes the empirical analysis conclusions of Waddock and Graves, Wang and Wang, Kabir and Thai, and Zheng Pei, thus lending persuasiveness to the stakeholder theory and quality management ideas presented in this paper [4], [10], [17, [21]. This outcome is also evidence of the strategic social responsibility of "making the company better by doing good things" [27].

\begin{tabular}{|c|c|c|c|c|c|c|c|c|c|}
\hline Variables & Mean & SD & 1 & 2 & 3 & 4 & 5 & 6 & 7 \\
\hline 1.Size ${ }_{t}$ & 61061 & 91614 & 1 & & & & & & \\
\hline 2. Risk $_{t}$ & 0.68 & 0.1732 & $0.272^{* *}$ & 1 & & & & & \\
\hline 3. Strut & 71.81 & 28.51 & $-0.231^{* *}$ & $-0.14^{*}$ & 1 & & & & \\
\hline 4. $\mathrm{ESR}_{\mathrm{t}}$ & 0.00068 & 0.0033 & -0.052 & -0.045 & 0.025 & 1 & & & \\
\hline 5. $\mathrm{ROE}_{\mathrm{t}+1}$ & 0.0939 & 0.11 & $0.218^{* *}$ & 0.100 & 0.077 & $0.126^{*}$ & 1 & & \\
\hline 6. $\mathrm{TQ}_{\mathrm{t}+1}$ & 0.049 & 0.215 & $0.162^{* *}$ & 0.079 & 0.061 & 0.110 & $0.451^{* *}$ & 1 & \\
\hline 7.CSR & 42.69 & 10.11 & $0.550^{* *}$ & $0.147^{*}$ & $-0.172^{* *}$ & -0.052 & $0.197^{* *}$ & 0.096 & 1 \\
\hline
\end{tabular}

Note. $N=285 .{ }^{*} p<0.5 ;{ }^{* *} p<0.05 ;{ }^{* * *} p<0.01$.

Table II. The impact of state-owned listed companies' CSR on CFP.

\begin{tabular}{ccccccc}
\hline \hline \multirow{2}{*}{ Variables } & \multicolumn{3}{c}{ Model 1 } & \multicolumn{3}{c}{ Model 2 } \\
& \multicolumn{3}{c}{ DV: ROE } & \multicolumn{3}{c}{ DV: Tobin's Q } \\
\cline { 2 - 6 } & $\beta$ & T & VIF & $\beta$ & T & VIF \\
CSR & $0.302^{* *}$ & 2.879 & 3.378 & $0.242^{*}$ & 2.275 & 3.378 \\
Size & 0.064 & 0.754 & 2.209 & 0.032 & 0.375 & 2.209 \\
Risk & 0.068 & 1.130 & 1.097 & 0.064 & 1.052 & 1.097
\end{tabular}


INTERNATIONAL JOURNAL OF CIRCUITS, SYSTEMS AND SIGNAL PROCESSING

\begin{tabular}{|c|c|c|c|c|c|}
\hline Stru & $0.146^{*}$ & 2.469 & 1.068 & 0.112 & 1.878 \\
\hline T2011 & $0.229^{*}$ & 2.260 & 3.146 & $0.293^{* *}$ & 2.852 \\
\hline T2012 & $0.160^{*}$ & 2.014 & 1.948 & 0.112 & 1.382 \\
\hline djusted $\mathrm{R}^{2}$ & & 0.076 & & & 0.048 \\
\hline D.W. & & 2.056 & & & 1.973 \\
\hline Model F & & $4.867^{* * *}$ & & & $3.393^{* *}$ \\
\hline
\end{tabular}

Note. $N=285$. Standardized regression coefficients are reported. ${ }^{*} p<0.05 ;{ }^{* *} p<0.01 ;{ }^{* * * *} p<0.001$.

This shows that the state-owned listed enterprises can improve their financial performance based on accounting indicators by continuously enhancing the trust with stakeholders, strengthening the interaction with stakeholders, actively participating in CSR initiatives. The conclusion confirms the view that state-owned enterprises are the vanguard of social responsibility. The results also further encourage the state-owned enterprises to optimize the level of social responsibility management and proactively embed social responsibility into the process of enterprise strategy formulation and operation. Although, the conclusion of hypothesis $1 \mathrm{~b}$ is consistent with the research results of Luo, Bhattacharya, Wang et al., it is contrary to the research results of Wang Qian and Fan Qi [20], [24], [28], [29]. The author believes that the main reason for the inconsistent conclusion about the impact of CSR on Tobin's Q lies in the timing of different research samples.

\section{Test results and discussion of the moderating effects}

On the foundation of the basic model tests, we further investigate the regulating effect of the shareholding ratio of executives on the CSR-CFP relationship of state-owned listed companies (Table III). To overcome multicollinearity that may be caused by adding interactive items and eliminating the difference between the mean values of different variables, we perform centralized conversion of the variables that comprise the interactive items based on the literature. Here, Model 3 and Model 4 use ROE as the dependent variable, and Model 5 and Model 6 use Tobin's Q as the dependent variable. As shown in Table III, the F value, D.W. value and VIF value of each model meet the fit requirements. In Model 3 and Model 5, we find that after adding the shareholding ratio of executives and control variables, respectively, the CSR of the state-owned listed companies in year $t$ still affects company ROE and Tobin's Q in the $t+1$ th year. This outcome again supports Hypothesis 1a and
Hypothesis $1 \mathrm{~b}$. We also determined that the shareholding ratio of executives positively affects company ROE for year $\mathrm{t}+1$. However, its impact on Tobin's Q does not surpass the significance level of $p<0.05$, indicating that the shareholding ratio of executives has a more significant impact on accounting indicators-based CFP.

On this basis, we also found similar differences in Model 4 and Model 6 when testing the moderating effect. In Model 4, with ROE as the dependent variable, the moderating effect of the shareholding ratio of executives on the relationship between CSR and CFP of state-owned listed companies was verified $(\mathrm{t}=$ $2.86, \mathrm{p}<0.01)$. That is, Hypothesis $2 \mathrm{a}$ is supported. In addition, in the model with Tobin's $Q$ as the dependent variable, the shareholding ratio of executives does not exhibit the positive effect of amplifying the positive relationship between CSR and CFP of state-owned listed companies $(t=1.05)$. That is, Hypothesis $2 \mathrm{~b}$ is not supported. In order to further reveal the essence of the interaction effect, this article draws Fig. 1 to show the moderating effects. It can be seen from Fig. 1 that the positive effect of social responsibility of state-owned listed companies on ROE will be more obvious when the proportion of senior executives holding shares is higher. We believe that the results for the described differential moderating effects can be explained by the "economic rational choice" caused by the executives' shareholding in the upper echelons theory mechanism, and the executives' shareholding reduction policies are mostly due to the arrangement of accounting indicators. Therefore, senior executives will pay more attention to the performance calculated by accounting indicators.

Table III. Hierarchical regression analyses.

\begin{tabular}{|c|c|c|c|c|c|c|c|c|c|c|}
\hline \multirow[t]{2}{*}{ Variables } & \multicolumn{2}{|c|}{$\begin{array}{l}\text { Model } 3 \\
\text { DV: ROE }\end{array}$} & \multicolumn{3}{|c|}{$\begin{array}{c}\text { Model } 4 \\
\text { DV: ROE }\end{array}$} & \multicolumn{2}{|c|}{$\begin{array}{c}\text { Model } 5 \\
\text { DV: Tobin's Q }\end{array}$} & \multicolumn{3}{|c|}{$\begin{array}{c}\text { Model } 6 \\
\text { DV: Tobin's Q }\end{array}$} \\
\hline & $\beta$ & $\mathrm{T}$ & $\beta$ & $\mathrm{T}$ & VIF & $\beta$ & $\mathrm{T}$ & $\beta$ & $\mathrm{T}$ & VIF \\
\hline Size & 0.071 & 0.84 & 0.092 & 1.10 & 2.229 & 0.038 & 0.44 & 0.046 & 0.54 & 2.229 \\
\hline Risk & 0.071 & 1.21 & 0.068 & 1.16 & 1.099 & 0.067 & 1.11 & 0.066 & 1.09 & 1.099 \\
\hline Stru & $0.144^{*}$ & 2.46 & $0.136^{*}$ & 2.36 & 1.071 & 0.111 & 1.87 & 0.108 & 1.82 & 1.071 \\
\hline T2011 & $0.220^{*}$ & 2.19 & $0.222^{*}$ & 2.24 & 3.150 & $0.286^{* *}$ & 2.80 & $0.286^{* *}$ & 2.80 & 3.150 \\
\hline T2012 & $0.160^{*}$ & 2.03 & $0.162^{*}$ & 2.08 & 1.948 & 0.112 & 1.39 & 0.112 & 1.40 & 1.948 \\
\hline
\end{tabular}


INTERNATIONAL JOURNAL OF CIRCUITS, SYSTEMS AND SIGNAL PROCESSING

DOI: $10.46300 / 9106.2021 .15 .82$

\begin{tabular}{|c|c|c|c|c|c|c|c|c|c|c|}
\hline CSR & $0.300^{* *}$ & 2.88 & $0.294^{* *}$ & 2.86 & 3.379 & $0.240^{*}$ & 2.27 & $0.238^{*}$ & 2.25 & 3.379 \\
\hline ESR & $0.137^{*}$ & 2.42 & $0.250^{* * *}$ & 3.65 & 1.506 & 0.112 & 1.93 & $0.154^{* *}$ & 2.18 & 1.506 \\
\hline $\begin{array}{c}\mathrm{CSR} \times \\
\mathrm{ESR}\end{array}$ & & & $0.196^{* *}$ & 2.86 & 1.509 & & & 0.074 & 1.05 & 1.509 \\
\hline $\begin{array}{c}\text { Adjusted } \\
\mathrm{R}^{2}\end{array}$ & 0.091 & & 0.114 & D.V & 2.055 & 0.057 & & 0.058 & D.V & $=1.989$ \\
\hline Model F & $5.082^{* * *}$ & & & $5.583^{* * *}$ & & $3.469^{*}$ & & & $3.173^{* *}$ & \\
\hline
\end{tabular}

Note. $N=285$. Standardized regression coefficients are reported. ${ }^{*} P<0.05,{ }^{* *} P<0.01,{ }^{* * *} P<0.001$.

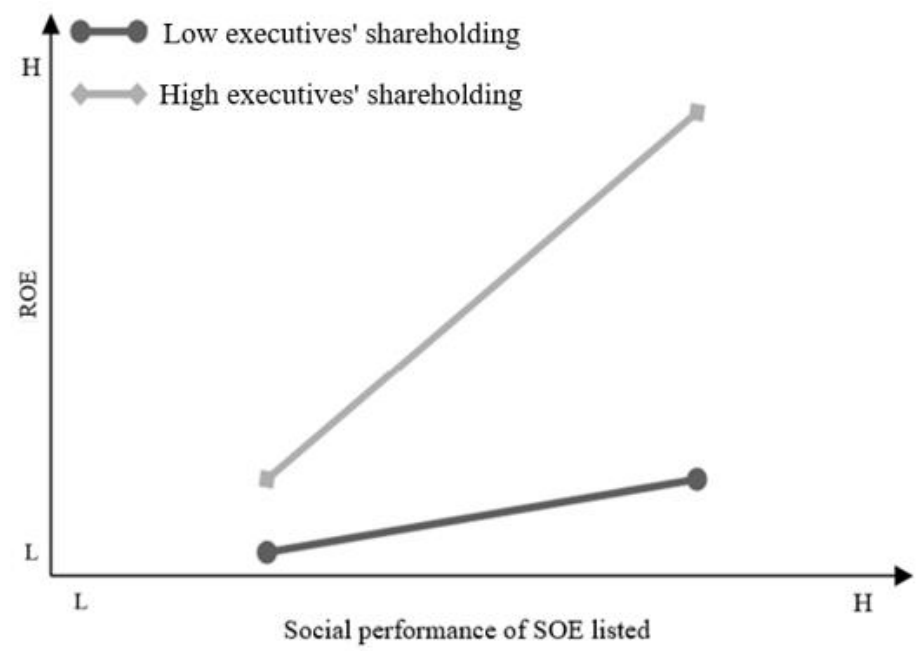

Fig.1 The moderating effects of senior executives' shareholding ratio

\section{Conclusion}

In Modern Systems Theory the mathematical modelling and simulation plays an important role. Applied Systems Theory and Financial Systems have received considerable attention among the researchers and practitioners recently. Against the background of continuing reform of state-owned enterprises and optimization of corporate governance as well as academic interest in the relationship between CSR and CFP in China, this study conducted quantitative analysis with a secondary data sample of 285 Chinese state-owned listed companies. This study draws conclusions through empirical results analysis that the social responsibility of state-owned listed companies has a positive impact on the economic performance based on accounting indicators lagging behind one year, and also has a positive impact on the economic performance based on capital market indicators lagging behind one year. In other words, better social responsibility of state-owned listed companies will bring better economic performance. The shareholding ratio of executives of listed companies amplifies the impact of CSR on financial performance based on accounting indicators and plays a positive moderating role. The research uses quantitative methods and objective data to contribute to the debate on the relationship between CSR and CFP [1]-[3], [6]. In addition, our results enrich the explanation mechanism of stakeholder theory based on the idea of quality management and explain how CSR affects CFP from the perspective of the dynamic change of the internal management mode. Methodologically, this study combines the capital attributes, management culture and scale characteristics of state-owned listed companies and conducts embedded analysis on the influences of these variables. This approach compensates for the lack of concrete discussion of mechanisms in previous research and to a certain extent alleviates social and public concerns regarding the effectiveness of state-owned enterprises in fulfilling their social responsibilities [7], [8], [11].

This strategy not only expands the scholarly understanding of the relationship between CSR and CFP of state-owned listed companies but also helps determine the internal governance conditions that apply between optimizing social responsibility and gaining a competitive advantage for such companies [12], [14]. Meanwhile, it highlights the important impact of the company's institutional arrangements on CSR strategies and corporate operational benefits, and provides direct evidence and key elements for the application of strategic social responsibility theories in emerging economies [23], [27].

This research has found conclusions with theoretical significance and practical inspiration. Meanwhile, this research also has some limitations. First, taking state-owned listed companies as a sample may affect the generalizability of the research conclusions. Second, we need to pay attention to the influence of other potential moderator variables, such as dynamic capability, institutional environment, organizational learning and so on.

On the basis of this research, there is value for further exploration in the following directions. First, this study uses cross-sectional data for empirical testing. In the future, we can 
try to use dynamic analysis to conduct longitudinal research, and to explore the relationship between CSR and CFP. Second, future research could collect sample data of non-state-owned enterprises for comparative research and enhance the universality of research conclusions.

\section{REFERENCES}

[1] M. L. Barnett and R. M. Salomon, "Does it pay to be really good? Addressing the shape of the relationship between social and financial performance," Strategic Management Journal, vol. 33, pp.1304-1320, Nov. 2012.

[2] L. Chen, A. Feldmann and O. Tang, "The relationship between disclosures of corporate social performance and financial performance: Evidences from GRI reports in manufacturing industry," International Journal of Production Economics, vol.170, pp.445-456, Dec. 2015.

[3] J. Nollet, G. Filis and E. Mitrokostas, "Corporate social responsibility and financial performance: A non-linear and disaggregated approach," Economic Modelling, vol.52, pp.400-407, Jan. 2016.

[4] P. Zheng, Y. Li and Y. He, "Research on the impact of corporate social responsibility on financial performance - based on empirical evidence of Chinese listed companies," The Theory and Practice of Finance and Economics, vol.41, pp.64-71, Jun. 2020.

[5] P. Zhong, T. Wu, X. Li. "An Empirical Study on the Relationship among Corporate Social Responsibility Report, Social Irresponsibility and Financial Performance of Listed Companies," Forecasting, vol.40, pp.17-23. Jan. 2021.

[6] L. E. Isaksson and A. G. Woodside, "Modeling firm heterogeneity in corporate social performance and financial performance," Journal of Business Research, vol.69, pp.3285-3314, Sep. 2016.

[7] P. H. Cunningham, "State-owned enterprises: pursuing responsibility in corporate social responsibility," Management Communication Quarterly, vol.25, pp.718-724, Nov. 2011.

[8] W. Li and R. Zhang, "Corporate Social Responsibility, Ownership Structure, and Political Interference: Evidence from China," Journal of Business Ethics, vol.96, pp.631-645, Apr. 2010.

[9] H. Yang and Q. Deng, "Study of Social Responsibility and Achievements of China's State-owned Enterprises: Based on sustainable Development Perspective," Journal of Zhongnan University of Economics and Law, vol.1, pp.120-127, 2011.

[10] W. Wang and S. Wang, "Research on the relatedness between social responsibility and performance of China's State-owned Enterprises," China Soft Science, pp.131-137, 2014.

[11] Q. Zhu, J. Liu and K. Lai, "Corporate social responsibility practices and performance improvement among Chinese national state-owned enterprises," International Journal of Production Economics, vol.171, pp.417-426, Jan. 2016.

[12] R. V. Aguilera, D. E. Rupp, C. A. Williams and J. Ganapathi, "Putting the $\mathrm{S}$ back in corporate social responsibility: A multilevel theory of social change in organizations," Academy of Management Review, vol.32, pp.836-863, Jul. 2007.

[13]R. A. Johnson and D. W. Greening, "The effects of corporate governance and institutional ownership types on corporate social performance," Academy of Management Journal, vol.42, pp.564-576, Oct. 1999.

[14] C. W. Peng and M. L. Yang, "The Effect of Corporate Social Performance on Financial Performance: The Moderating Effect of Ownership Concentration," Journal of Business Ethics, vol.123, pp.171-182, 2014.

[15] P. S. Saeidi, S. Sofan, P. Saeidi, S. P. Saeidi and A. S. Saaeidi, "How does corporate social responsibility contribute to firm financial performance? The mediating role of competitive advantage, reputation, and customer satisfaction," Journal of Business Research, vol.68, pp.341-350, Feb. 2015.

[16] M. Friedman, "The social responsibility of business is to increase its profits," The New York Times Magazine, pp.122-124, Sep. 1970.

[17] S. A. Waddock and S. B. Graves, "The corporate social performance-financial performance link," Strategic Management Journal, vol.18, pp.303-319, Apr. 1997.

[18] J. B. McGuire, A. Sundgren and T. Schneeweis, "Corporate social responsibility and firm financial performance," Academy of management Journal, vol.31, pp.854-872, Dec. 1988.

[19] K. B. Backhaus, B. A. Stone and K. Heiner, "Exploring the relationship between corporate social performance and employer attractiveness," Business \& Society, vol.41, pp.292-318, Sep. 2002.

[20]X. Luo and C. B. Bhattacharya, "Corporate social responsibility, customer satisfaction, and market value," Journal of marketing, vol.70, pp.1-18, Oct. 2006.

[21] R. Kabir and H. M. Thai, "Does corporate governance shape the relationship between corporate social responsibility and financial performance?" Pacific Accounting Review, vol.29, pp.227-258, Apr. 2017.

[22] O. V. Petrenko, F. Aime, J. Ridge and A. Hill, "Corporate social responsibility or CEO narcissism? CSR motivations and organizational performance" Strategic Management Journal, vol.37, pp.262-279, Feb. 2016.

[23] B. W. Husted and D. B. Allen, "Corporate Social Strategy in Multinational Enterprises: Antecedents and Value Creation," Journal of Business Ethics, vol.74, pp.345-361, Jul. 2007.

[24]H. Wang, J. Choi and J. Li, "Too Little or Too Much? Untangling the Relationship Between Corporate Philanthropy and Firm Financial Performance," Organization Science, vol.19, pp.143-159, Feb. 2008.

[25] W. Lu, K. W. Chau, H. Wang and W. Pan, "A decade' s debate on the nexus between corporate social and corporate financial performance: a critical review of empirical studies 2002-2011," Journal of Cleaner Production, vol.79, pp.195-206, Sep. 2014,

[26]H. Wang and J. Choi, "A new look at the corporate social-financial performance relationship the moderating roles of temporal and interdomain consistency in corporate 
social performance," Journal of Management, vol.39, pp.416-441, Jul. 2013.

[27] L. Burke and J. M. Logsdon, "How corporate social responsibility pays off," Long Range Planning, vol.29, pp.495-502, Aug. 1996.

[28] H. Wang, C. Qian, “Corporate Philanthropy and Corporate Financial Performance: The Roles of Stakeholder Response and Political Access," Academy of Management Journal, vol.54, pp.1159-1181, Dec. 2011,

[29]Q. Fan, "Research on the Correlation between Social Responsibility and Financial Performance of State-owned Listed Companies," Finance and Accounting Monthly, pp.25-28, Jun. 2013.

[30] Divine Chinyere Samuel-Hope, Omankhanlen Alexander Ehimare, Godswill Osagie Osuma, The Impact of Financial Deepening on Economic Growth in Nigeria (1981-2018), WSEAS Transactions on Business and Economics, pp. 977-986, Volume 17, 2020

[31] Isibor Areghan Akhanolu, Omankhanlen Alexander Ehimare, Chima Menyelim Mathias, Komolafe Titilope Deborah, Okereke Karachi Yvonne, The Impact of Credit Risk Management and Macroeconomic Variables on Bank Performance in Nigeria, WSEAS Transactions on Business and Economics, pp. 956-965, Volume 17, 2020

[32] Ming-Jie Li, Jie Zhang, Yu-Lin Zhu, Evaluation on the Warning-Degree of the Ecological Carrying Capacity of Guangzhou City based on the DPSIR Model, WSEAS Transactions on Business and Economics, pp. 869-878, Volume 17, 2020

[33] Isibor Areghan Akhanolu, Omankhanlen Alexander Ehimare, Chima Menyelim Mathias, Komolafe Titilope Deborah, Okereke Karachi Yvonne, The Impact of Credit Risk Management and Macroeconomic Variables on Bank Performance in Nigeria, WSEAS Transactions on Business and Economics, pp. 956-965, Volume 17, 2020

[34] Abiola Babajide, Funso Abiodun Okunlola, Lawal Adedoyin, Tochukwu Okafor, Areghan Isibor, Analysis of Banks Profitability: Domestic and Foreign Comparison, WSEAS Transactions on Business and Economics, pp. 947-955, Volume 17, 2020

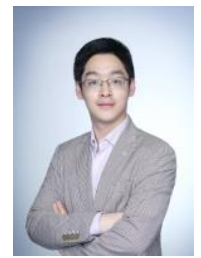

Qi Tai Song SHEN was born in Shaoxing, China, in 1982. He received a $\mathrm{PhD}$ degree in Management from Zhejiang University, Hangzhou, China, in 2010. He is an associate professor in the Digital Transformation and Social Responsibility Management Research Center at Zhejiang University City College. His major research interests are in the area of social responsibility management.

\section{Contribution of individual authors to the creation of a scientific article (ghostwriting policy)}

Qi Tai Song Shen was responsible for the topic selection, research design, model construction, data analysis and thesis writing.

Xiaofei Wang has carried out data collection, data analysis and thesis writing.

Jian $\mathrm{Yu}$ has contributed for the topic selection and data analysis.

\section{Creative Commons Attribution License 4.0 (Attribution 4.0 International, CC BY 4.0)}

This article is published under the terms of the Creative Commons Attribution License 4.0

https://creativecommons.org/licenses/by/4.0/deed.en_US 